\title{
Comparative Performance of Four Indian Pharmacognosy Journals
}

\author{
K. K. Mueen Ahmed' ${ }^{1}$ Madhu Bansal ${ }^{2}$, B. M. Gupta ${ }^{3}$ \\ 'Phcog.Net, 17, Buddha Vihar Road, Cox Town, Bengaluru 560005, INDIA. \\ 2Department of Mathematics, Panjab University, A,C. Joshi Library, Chandigarh-160014, INDIA. \\ ${ }^{3} 1173$ Sector 15, Panchkula 134113, Haryana, INDIA.
}

\begin{abstract}
The study presents an analysis of articles covered in four pharmacognosy journals during 2010-13 and the citations obtained by these articles during 2010-15. The study developed immediacy index and impact factor, besides identifying high cited articles published in these four journals. The findings revealed that Pharmacognosy Review has performed the best, followed by Pharmacognosy Magazine, Pharmacognosy Research and Pharmacognosy Journal.
\end{abstract}

Key words: Pharmacognosy Journals, India, Citation analysis, Performance evaluation, Scientometrics

Correspondence:

Madhu Bansal, Department of Mathematics, Panjab University, Chandigarh-160014, INDIA.

Email: madhu@pu.ac.in

DOI: 10.5530/PTB.2016.2.3

\section{INTRODUCTION}

Pharmacy (or pharmacology) is one of the disciplines under biomedical and health sciences and it is the profession responsible for the preparation, dispensing and appropriate use of medication and which provides services to achieve optimal therapeutic outcomes. It deals with the production of pharmaceutical products, development of the methods or processes of production and quality control. In terms of $\mathrm{R} \& \mathrm{D}$, it is concerned with synthesis of new drugs (what is commonly referred to as molecules), new processes, clinical testing of the effects of such drugs on animals and humans, and obtaining the required license from the drug control authorities. Pharmacology has a long legacy of research of more than 100 years. There are over 225 programs in pharmacy conducted by different universities in India. ${ }^{1}$ A large number of journals (over 35 ) are published in India in pharmacology related research, some of them originated as early as 1940.

Pharmacognosy is a one of the branch of Pharmacy and contributes drugs from the natural sources, as natural products are the most consistent and successful source of drugs. In India, Ayurveda remains one of the most ancient and living traditions, practiced for the treatment of various diseases and disorders. India has many plant species, and medicinal properties have been assigned to several thousand of them. Many major institutes and research centers are currently involved in exploring this opportunity to investigate newer drugs from the ancient principles of Ayurveda.

Researchers believe in combining the strengths of Ayurveda with modern scientific techniques such as NMR, MS, and chromatographic techniques to provide new functional leads with high therapeutic value in a short span of time. But natural products research often faces many hurdles, which hinders drug development. We believe that natural products research information can potentially benefit many researchers involved in this area. We also believe that research on natural products is often delayed by a lack of necessary information about medicinal plants. Phcog.Net-A Platform for Natural Product Researchers was created to combat these problems. It makes innovative use of the best tools for information dissemination to overcome the hurdles to Natural Product Research. Phcog.Net is a private organization founded by Dr. Ahmed in the year 2004 and it is dedicated to Natural Products Research to develop promising drugs. Their main mission is to make information on herbal drug research readily available in different formats to suit the individual needs. A long term objective is to provide high quality, accurate, and necessary information to enhance herbal drug research. Phcog.Net is a private organization dedicated to Natural Products Research in order to develop promising drugs.

In the past few studies dealing with performance of journals in terms of various indices have been conducted and reported in the literature. These studies have explored the authorship pattern, institutional affiliation, average length of articles, number of contributions, number of references appended, etc. A similar study on two Indian library science journals have been published by Garg and Bebi, ${ }^{2}$ which analysed the number of articles published by these two journals during 2010-13. To make comparative assessment of the performance of four Indian pharmacognosy journals, based on their publication and citation indices. In particular it focuses on; (i) to find the number of articles published during 2010-13 and the number of citations received by these articles during 2010-15 (June); (ii) to determine of extent of citations obtained by these journals, (iii) to identify the high cited papers and authors and (iv) to calculate the immediacy index for years from 2010-to 2013 and impact factor for the years from 2012 to 2014.

\section{METHOD}

The data for the present study consist of articles published in four Indian pharmacognosy journals, namely Pharmacognosy Journal, Pharmacognosy Magazine, Pharmacognosy Research and Pharmacognosy Reviews as indexed in Scopus international database from 2010 to 2013. Citations of the publications indexed in these four journals were obtained from 2010 till June 2015. The results were tabulated and analyzed as per the objectives of the study.

\section{RESULTS AND DISCUSSION}

Articles published during 2010-13 and their pattern of citations: Table 1 presents the data on the number of articles published in the four selected 
Table 1: Year-wise distribution of articles and their citations

\begin{tabular}{|c|c|c|c|c|c|c|c|c|c|c|c|c|}
\hline \multirow[t]{2}{*}{ Year } & \multicolumn{3}{|c|}{$\begin{array}{c}\text { Pharmacognosy Journal } \\
\text { (P JOUR) }\end{array}$} & \multicolumn{3}{|c|}{$\begin{array}{l}\text { Pharmacognosy Magazine } \\
\text { (P MAGA) }\end{array}$} & \multicolumn{3}{|c|}{$\begin{array}{c}\text { Pharmacognosy Research } \\
\text { (P RES) }\end{array}$} & \multicolumn{3}{|c|}{$\begin{array}{c}\text { Pharmacognosy Review } \\
\text { (P REV) }\end{array}$} \\
\hline & NOA & NOC & CPP & NOA & NOC & CPP & NOA & NOC & CPP & NOA & NOC & CPP \\
\hline 2010 & 139 & 273 & 1.96 & 67 & 664 & 9.91 & 79 & 480 & 6.08 & 29 & 498 & 17.17 \\
\hline 2011 & 137 & 203 & 1.48 & 58 & 366 & 6.31 & 49 & 284 & 5.8 & 23 & 338 & 14.7 \\
\hline 2012 & 89 & 118 & 1.33 & 56 & 188 & 3.36 & 39 & 154 & 3.95 & 21 & 124 & 5.905 \\
\hline 2013 & 55 & 57 & 1.04 & 43 & 65 & 1.51 & 59 & 88 & 1.49 & 25 & 56 & 2.24 \\
\hline Total & 420 & 651 & 1.55 & 224 & 1283 & 5.73 & 218 & 1006 & 4.61 & 98 & 1016 & 10.37 \\
\hline
\end{tabular}

$\mathrm{NOA}=$ Number of Articles; NOC=Number of Citations; $\mathrm{CPP}=$ Citations Per Publication.

Table 2: Distribution of citations of articles

\begin{tabular}{|c|c|c|c|c|c|c|c|c|}
\hline \multirow[b]{2}{*}{$\begin{array}{l}\text { Citations } \\
\text { (A) }\end{array}$} & \multicolumn{2}{|c|}{$\begin{array}{c}\text { Pharmacognosy Journal } \\
\text { (P JOUR) }\end{array}$} & \multicolumn{2}{|c|}{$\begin{array}{c}\text { Pharmacognosy } \\
\text { Magazine (P MAGA) }\end{array}$} & \multicolumn{2}{|c|}{$\begin{array}{l}\text { Pharmacognosy } \\
\text { Research (P RES) }\end{array}$} & \multicolumn{2}{|c|}{$\begin{array}{c}\text { Pharmacognosy Review } \\
\text { (P REV) }\end{array}$} \\
\hline & NOA & TC & NOA & TC & NOA & TC & NOA & TC \\
\hline 0 & 154 & 0 & 39 & 0 & 34 & 0 & 8 & 0 \\
\hline 1 & 98 & 98 & 25 & 25 & 34 & 34 & 9 & 9 \\
\hline 2 & 75 & 150 & 23 & 46 & 29 & 58 & 5 & 10 \\
\hline 3 & 38 & 114 & 23 & 69 & 17 & 51 & 14 & 42 \\
\hline 4 & 30 & 120 & 18 & 72 & 20 & 80 & 4 & 16 \\
\hline 5 & 11 & 55 & 14 & 70 & 11 & 55 & 6 & 30 \\
\hline 6-10 & 12 & 83 & 43 & 332 & 49 & 364 & 24 & 199 \\
\hline $11-15$ & 1 & 12 & 23 & 284 & 18 & 229 & 12 & 155 \\
\hline $16-20$ & 1 & 19 & 7 & 202 & 2 & 36 & 7 & 127 \\
\hline $21-25$ & & & 2 & 46 & 3 & 67 & 4 & 95 \\
\hline $26-30$ & & & 5 & 137 & 2 & 0 & 0 & 0 \\
\hline $31-35$ & & & & & 1 & 32 & 2 & 63 \\
\hline$>35$ & & & & & & & 3 & 271 \\
\hline Total & 420 & 651 & 224 & 1283 & 218 & 1006 & 98 & 1016 \\
\hline
\end{tabular}

NOA=Number of Articles; TC=Total Citations.

Table 3: Impact Factor of Journals

\begin{tabular}{|c|c|c|c|c|c|c|c|c|}
\hline \multirow{2}{*}{$\begin{array}{l}\text { Time } \\
\text { Period }\end{array}$} & \multicolumn{2}{|c|}{$\begin{array}{c}\text { Pharmacognosy Journal } \\
\text { (P JOUR) }\end{array}$} & \multicolumn{2}{|c|}{$\begin{array}{c}\text { Pharmacognosy } \\
\text { Magazine (P MAGA) }\end{array}$} & \multicolumn{2}{|c|}{$\begin{array}{l}\text { Pharmacognosy } \\
\text { Research (P RES) }\end{array}$} & \multicolumn{2}{|c|}{$\begin{array}{c}\text { Pharmacognosy Review } \\
\text { (P REV) }\end{array}$} \\
\hline & NTC & NOA & NTC & NOA & NTC & NOA & NTC & NOA \\
\hline $\begin{array}{c}2010-11 \\
\text { articles } \\
\text { cited in } \\
2012\end{array}$ & 119 & 276 & 263 & 128 & 174 & 128 & 126 & 52 \\
\hline IF for 2012 & \multicolumn{2}{|c|}{0.431} & \multicolumn{2}{|c|}{2.055} & \multicolumn{2}{|c|}{1.359} & \multicolumn{2}{|c|}{2.423} \\
\hline $\begin{array}{c}2011-12 \\
\text { articles } \\
\text { cited in } \\
2013\end{array}$ & 73 & 226 & 150 & 114 & 141 & 88 & 143 & 44 \\
\hline IF for 2013 & \multicolumn{2}{|c|}{0.323} & \multicolumn{2}{|c|}{1.316} & \multicolumn{2}{|c|}{1.602} & \multicolumn{2}{|c|}{3.250} \\
\hline $\begin{array}{c}2012-13 \\
\text { articles } \\
\text { cited in } \\
2014\end{array}$ & 82 & 144 & 137 & 99 & 103 & 98 & 72 & 46 \\
\hline IF for 2014 & \multicolumn{2}{|c|}{0.494} & \multicolumn{2}{|c|}{1.384} & \multicolumn{2}{|c|}{1.051} & \multicolumn{2}{|c|}{1.565} \\
\hline
\end{tabular}

NTC $=$ Number of Times Cited; NOA=Number of Articles. 
Ahmed et al:: Comparative Performance of Four Indian Pharmacognosy Journals

Table 4: Immediacy Index of the journals

\begin{tabular}{|c|c|c|c|c|c|c|c|c|c|c|c|c|}
\hline \multirow[t]{2}{*}{ Period } & \multicolumn{3}{|c|}{$\begin{array}{c}\text { Pharmacognosy Journal } \\
\text { (P JOUR) }\end{array}$} & \multicolumn{3}{|c|}{$\begin{array}{c}\text { Pharmacognosy Magazine ( } P \\
\text { MAGA) }\end{array}$} & \multicolumn{3}{|c|}{$\begin{array}{c}\text { Pharmacognosy Research } \\
\text { (P RES) }\end{array}$} & \multicolumn{3}{|c|}{$\begin{array}{c}\text { Pharmacognosy Review } \\
\text { (P REV) }\end{array}$} \\
\hline & NOP & $\mathrm{NOC}$ & II & NOP & NOC & II & NOP & NOC & II & NOP & NOC & II \\
\hline 2010 & 139 & 65 & 0.47 & 67 & 131 & 1.96 & 79 & 74 & 0.94 & 29 & 40 & 1.38 \\
\hline 2011 & 137 & 52 & 0.38 & 58 & 82 & 1.41 & 49 & 58 & 1.18 & 23 & 61 & 2.65 \\
\hline 2012 & 89 & 33 & 0.37 & 56 & 44 & 0.79 & 39 & 48 & 1.23 & 21 & 38 & 1.81 \\
\hline 2013 & 55 & 28 & 0.51 & 43 & 14 & 0.33 & 59 & 43 & 0.73 & 13 & 26 & 2.00 \\
\hline Total & 420 & 178 & 0.42 & 224 & 271 & 1.21 & 218 & 223 & 1.02 & 98 & 165 & 1.68 \\
\hline
\end{tabular}

$\mathrm{NOP}=$ Number of Papers; NOC=Number of Citations; II=Immediacy Index.

Indian pharmacognosy journals during 2010-13 and the citations obtained by them during 2010-15 (June). It was noticed that Pharmacognosy Journal published the largest number of publications (420), followed by Pharmacognosy Magazine (224), Pharmacognosy Research (218) and Pharmacognosy Reviews (98) during 2010-13. The average number of articles per year was highest (105) in Pharmacognosy Journal, followed by 56 in Pharmacognosy Magazine, 53.6 in Pharmacognosy Research and 24.5 in Pharmacognosy Review during 2010-13. A citation per paper was highest (10.37) in Pharmacognosy Review, followed by 5.73 in Pharmacognosy Magazine, 4.61 in Pharmacognosy Research and 1.55 in Pharmacognosy Journal.

\section{Extent of Citations}

Table 2 presents the data on the extent of citations received by the four journals. It was observed that the total articles published in these four journals that did not get any citations were highest in $36.67 \%$ in Pharmacognosy Journal, followed by $17.41 \%$ in Pharmacognosy Magazine, $15.60 \%$ in Pharmacognosy Research and $8.16 \%$ in Pharmacognosy Review. Further the analysis of citation data of the four journals indicates the following number of articles in each journal received more than 10 or more than 20 citations: Pharmacognosy Magazine (37 and 7), Pharmacognosy Review (28 and 9), Pharmacognosy Research (26 and 6) and Pharmacognosy Journal ( 2 and 0 ). The list of papers receiving more than 20 citations is listed in Appendix 1.

\section{Impact Factor}

Data on the number of citations for the calculation of impact factor is shown in Table 3. The data indicates that Pharmacognosy Review has received the highest impact (increasing from 2.423 to 3.250), followed by Pharmacognosy Magazine (decreasing from 2.055 to 1.384), Pharmacognosy Research (decreasing from 1.359 to 1.051) and Pharmacognosy Journal (increasing from 0.431 to 0.494 ) from 2012 to 2014 (Table 3).

\section{Immediacy Index}

Immediacy index is a measure of how quickly articles published in a journal are cited in next 1 year after its publication year. Table 4 presents data on publications and citations registered by the four journals. It was observed that Pharmacognosy Review has received the highest immediacy index of 1.68 during 2010-13, followed by Pharmacognosy Magazine (1.21), Pharmacognosy Research (1.02) and Pharmacognosy Journal (0.42). The immediacy index has increased in case of Pharmacognosy Review and Journal and decreased in Pharmacognosy Magazine and Pharmacognosy Research from 2010 to 2013.

\section{SUMMARY}

The analysis of the data presented above indicates that average number of articles published per year was highest (105) in Pharmacognosy Journal, followed by Pharmacognosy Magazine (56), Pharmacognosy Research (53.6) and Pharmacognosy Review (24.5) during 20102013. Pharmacognosy Review has received the highest immediacy index of 1.68 during 2010-13, followed by Pharmacognosy Magazine (1.21), Pharmacognosy Research (1.02) and Pharmacognosy Journal (0.42). The immediacy index has increased in case of Pharmacognosy Review and Journal and decreased in Pharmacognosy Magazine and Pharmacognosy Research from 2010 to 2013. Similarly Pharmacognosy Review has received the highest impact (increasing from 2.423 to 3.250), followed by Pharmacognosy Magazine (decreasing from 2.055 to 1.384), Pharmacognosy Research (decreasing from 1.359 to 1.051) and Pharmacognosy Journal (increasing from 0.431 to 0.494 ) from 2012 to 2014. The extent of articles not receiving any citations were highest in $36.67 \%$ in Pharmacognosy Journal, followed by $17.41 \%$ in Pharmacognosy Magazine, $15.60 \%$ in Pharmacognosy Research and $8.16 \%$ in Pharmacognosy Review. In terms of higher number of citations (more than 10 and 20), the largest number were registered by Pharmacognosy Magazine (37 and 7), Pharmacognosy Reviews (28 and 9), Pharmacognosy Research (26 and 6) and Pharmacognosy Journal (2 and 0 ).

\section{CONCLUSION}

The four pharmacognosy journals under consideration have made importance contribution in field of natural products and pharmacognosy. A comparison of these journals in terms of productivity and citations indices have indicated that Pharmacognosy Reviews has performed the best, followed by Pharmacognosy Magazine, Pharmacognosy Research and Pharmacognosy Journal. Since reviews are expected to get more citations, therefore Pharmacognosy Reviews has performed the best in terms of citation impact indices. But compared to international data, these journals still to achieve a lot in terms of various citation indices. These journals should make efforts to raise their quality by raising their peer review standards and attract contribution by eminent scholars in the field.

\section{REFERENCES}

1. Pharmacy:Inroduction, 2000-2015. http://career.webindia123.com/career/options/health_medicine/pharmacy/intro.htm (Accessed on 31 August 2015)

2. Garg KC, and Bebi. A citation study of Annals of Library and Information Studies (ALIS) and DESIDOC Journal of Library and Information Technology (DJLIT). Annals of Library and Information Studies. 2014;61:212-16. 
Ahmed et al:: Comparative Performance of Four Indian Pharmacognosy Journals

\section{Appendix 1: List of High Cited Papers with 20 or more citations in four Indian Pharmcological Journals}

1. Lobo V, Patil A, Phatak A, Chandra N. Free radicals, antioxidants and functional foods: Impact on human health (Review). Pharmacognosy Reviews. 2010;4(8):pp.118-26. Cited 156 times. Birla College, Department of Botany, Kalyan, Maharastra, India.

2. Chahar MK, Sharma N, Dobhal MP, Joshi YC. Flavonoids: A versatile source of anticancer drugs. (Review ). Pharmacognosy Reviews. 2010;5(9):1-12. Cited 66 times University of Rajasthan, Department of Chemistry Jaipur, Rajasthan, India.

3. Kumar S, Narwal S, Kumar V, Prakash O. $\alpha$-glucosidase inhibitors from plants: A natural approach to treat diabetes (Review). Pharmacognosy Reviews. 2011:5(9):19-29. Cited 49 times. Institute of Pharmaceutical Sciences, Kurukshetra University, Kurukshetra-136 119, Haryana, India.

4. Pattanayak $P$, Behera $P$, Das D, Panda S. Ocimum sanctum Linn. A reservoir plant for therapeutic applications: An overview (Review). Pharmacognosy Reviews. 2010;4(7):95-105. Cited 33 times. Jeypore College of Pharmacy, Jeypore (K), Orissa 764 002, IndiaSOA University, School of Pharmaceutical Sciences, Bhubaneswar, Orissa, India.

5. Chan EWC, Soh EY, Tie PP, Law YP. Antioxidant and antibacterial properties of green, black, and herbal teas of Camellia sinensis (Article). Pharmacognosy Research. 2011;3(4):266-72. Cited 32 times. UCSI University, Faculty of Applied Sciences, Cheras, Kuala Lumpur, Malaysia.

6. Singh O, Khanam Z, Misra N, Srivastava MK. Chamomile (Matricaria chamomilla L.): An overview (Review). Pharmacognosy Reviews. 2011;5(9):82-95. Cited 30 times.

a Department of Biochemistry, Bundelkhand University, Jhansi, India b Department of Chemistry, Aligarh Muslim University, Aligarh, India ${ }^{\circ}$ Chemical Research Unit, Deptt. of Research in Unani Medicine, Aligarh Muslim University, Aligarh, India.

7. Samarghandian S, Boskabady MH, Davoodi S. Use of in vitro assays to assess the potential antiproliferative and cytotoxic effects of saffron (Crocus sativus L.) in human lung cancer cell line (Article). Pharmacognosy Magazine. 2010;6(24):309 14. Cited 29 times. Mashhad University Medical Sciences, Department of Physiology, Mashhad, Iran.

8. Chen X. Protective effects of quercetin on liver injury induced by ethanol (Article). Pharmacognosy Magazine. 2010;6(22):135-41. Cited 29 times. Institute of Medicinal Plant Development, Chinese Academy of Medical Sciences: Peking Union Medical College, 151 Malianwa North Road, Haidian District, Beijing 100193, China.

9. Metwally AM, Omar AA, Harraz FM, El Sohafy SM. Phytochemical investigation and antimicrobial activity of Psidium guajava L. leaves (Article). Pharmacognosy Magazine. 2010;6(23):212-8. Cited 27 times. Alexandria University, Faculty of Pharmacy, Department of Pharmacognosy, Alexandria, Egypt.

10. Sousa EO, Silva NF, Rodrigues FFG, Campos AR, Lima SG, Costa JGM. Chemical composition and resistance-modifying effect of the essential oil of Lantana camara linn (Article). Pharmacognosy Magazine. 2010;6(22):79-82. Cited 26 times. a Programa de Pós-Graduação em Bioprospecçã o Molecular, Departamento de Química Biológica, Universidade Regional Do Cariri, Rua Cel. Antônio Luiz 1161, Pimenta, 63105-000 Crato-CE, Brazil.

b Vice-Reitoria de Pesquisa e Pós-Graduação, Universidade de Fortaleza, Av. Washington Soares 1321, Edson Queiroz, 60811-905, Fortaleza-CE, Brazil. c Departamento de Química, Universidade Federal Do Piauí, Campus Universitário Ministro Petrônio Portella, 64049-550, Bairro Ininga,Teresina-PI, Brazil.

11. Adebayo $A H$, Tan NH, Akindahunsi AA, Zeng GZ, Zhang YM. Anticancer and antiradical scavenging activity of Ageratum conyzoides L. (Asteraceae) (Article). Pharmacognosy Magazine. 2010;6(21):62-6. Cited 26 times.

a State Key Laboratory of Phytochemistry and Plant Resources in West China, Kunming Institute of Botany, Chinese Academy of Sciences, Kunming 650204, China.

b Department of Biological Sciences, College of Science and Technology, Covenant University, PMB 1023, Ota, Ogun State, Nigeria.

c Department of Biochemistry, Federal University of Technology, Akure, Nigeria.

12. Srivastava $R$, Ahmed H, Dixit R, Dharamveer SS. Crocus sativus L.: A comprehensive review (Short Survey). Pharmacognosy Reviews. 2010;4(8):200-8.Cited 25 times. Babu Banarasi Das National Institute of Technology and Management, Faculty of Pharmacy, Lucknow, Uttar Pradesh, India.

13. Hajimehdipoor H, Shekarchi M, Khanavi M, Adib N, Amri M. A validated high performance liquid chromatography method for the analysis of thymol and carvacrol in Thymus vulgaris L. volatile oil (Article). Pharmacognosy Magazine.2010;6(23):154-8. Cited 25 times.

a Department of Traditional Pharmacy, School of Traditional Medicine, Shahid Beheshti University of Medical Sciences, Iran

${ }^{b}$ Department of Research and Development, Food and Drug Control Laboratories and Food and Drug Laboratory Research Center, MOH and ME, Tehran, Iran c Department of Pharmacognosy, Faculty of Pharmacy, Tehran University of Medical Sciences, Iran.

d Department of Pharmacognosy, Pharmaceutical Sciences Branch, Islamic Azad University, Tehran, Iran.

14. Korac RR, Khambholja KM. Potential of herbs in skin protection from ultraviolet radiation (Review). Pharmacognosy Reviews. 2011;5(10):164-73. Cited 24 times. a Department of Pharmaceutical Technology and Cosmetology, Faculty of Pharmacy, University in Belgrade, Vojvode Stepe 450, 11000 Belgrade, Serbia. b Departmant of Pharmacognosy, S. K. Patel College of Pharmaceutical Education and Research, Ganpat University, Mehsana-Gozaria Highway, Kherva, Gujarat, India.

15. Kumar GP, Khanum F. Neuroprotective potential of phytochemicals (Review). Pharmacognosy Reviews. 2012;6(12):81-90. Cited 23 times. Defence Food Research Laboratory (DRDO), Biochemistry and Nutrition Division, Mysore, India.

16. Rasineni K, Bellamkonda R, Singareddy SR, Desireddy S. Antihyperglycemic activity of Catharanthus roseus leaf powder in streptozotocin-induced diabetic rats (Article). Pharmacognosy Research. 2010;12(3):195-201. Cited 23 times. a Sri Krishnadevaraya University, Department of Biochemistry Anantapur-515

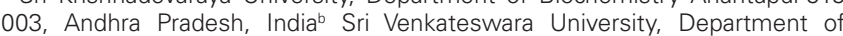
Biochemistry Tirupati-517502, Andhra Pradesh, India.

17. Kujur RS, Singh V, Ram M, Yadava HN, Singh KK, Kumari S, Roy BK. Antidiabetic activity and phytochemical screening of crude extract of Stevia rebaudiana in alloxan-induced diabetic rats (Article). Pharmacognosy Research. 2010; 2(4):258-63. Cited 22 times.

a Department of Pharmacology and Toxicology, College of Veterinary Science and A.H., Birsa Agricultural University, Ranchi-834 006, India.

b Department of Pharmacology, I.S.F. College of Pharmacy, Moga-142 001, Punjab, India.

c Department of Veterinary Pathology, College of Veterinary Science and A.H., Birsa Agricultural University, Ranchi-834 006, India.

18. Ramesh Ch, Pattar MG. Antimicrobial properties, antioxidant activity and bioactive compounds from six wild edible mushrooms of western ghats of Karnataka, India (Article). (2010) Pharmacognosy Research. 2010;2(2):107-112. Cited 22 times. Mycology Laboratory, Department of Botany, Karnatak University, Dharwad 580 003, Karnataka, India.

19. Kumar S, Malhotra R, Kumar D. Euphorbia hirta: Its chemistry, traditional and medicinal uses, and pharmacognosy activities (Review). Pharmacognosy Reviews. 2010;4(7):58-61. Cited 22 times. Institute of Pharmaceutical Sciences, Kurukshetra University, Kurukshetra-136 119, Haryana, India.

20. Gözlekçi S, Saraçoğlu O, Onursal E, Özgen M. Total phenolic distribution of juice, peel, and seed.extracts of four pomegranate cultivars (Article). Pharmacognosy Magazine. 2011;7(26):161-4. Cited 21 Times.

a Department of Horticulture, Akdeniz University Agricultural Faculty, 07058 Antalya, Turkey.

b Department of Horticulture, Gaziosmanpasa University Agricultural Faculty, 60240 Tokat, Turkey.

21. Kilicgun $H$, Altiner D. Correlation between antioxidant effect mechanisms and polyphenol content of Rosa canina (Article). Pharmacognosy Magazine. 2010:6(23):238-41. Cited 20 times.

a Department of Nutrition and Dietetic School of Health, University of Erzincan, Erzincan 24100, Turkey.

b Department of Biochemistry, Faculty of Pharmacy, Marmara University, Haydarpasa 81010, Istanbul, Turkey.

22. Sim KS, Sri Nurestri AM, Norhanom AW. Phenolic content and antioxidant activity of Pereskia grandifolia Haw. (Cactaceae) extracts (Article). Pharmacognosy Magazine. 2010;6(23):248-54. Cited 20 times.

a Institute of Biological Sciences, Faculty of Science, University of Malaya, 50603 Kuala Lumpur, Malaysia.

${ }^{\mathrm{b}}$ Centre for Foundation Studies in Science, University of Malaya, 50603 Kuala Lumpur, Malaysia.

23. Zheleva-Dimitrova D, Nedialkov $P$, Kitanov G. Radical scavenging and antioxidant activities of methanolic extracts from Hypericum species growing in Bulgaria (Article). Pharmacognosy Magazine. 2010;6(22):74-8. Cited 20 times. Department of Pharmacognosy, Faculty of Pharmacy, Medical University of Sofia, Dunav str. 2, 1000 Sofia, Bulgaria.

24. Saraf S, Kaur C. Phytoconstituents as photoprotective novel cosmetic formulations (Review). Pharmacognosy Reviews. 2010:4(7):1-11. Cited 20 times. University Institute of Pharmacy, Pt. Ravishankar Shukla University, Raipur (C.G.)492 010, India.

25. Arulmozhi , Krishnaveni M, Karthishwaran K, Dhamodharan G, Mirunalini S. Antioxidant and antihyperlipidemic effect of Solanum nigrum fruit extract on the experimental model against chronic ethanol toxicity (Article). Pharmacognosy Magazine. 2010;6(21):42-50. Cited 20 times. Department of Biochemistry and Biotechnology, Annamalai University, Annamalainagar-608 002, Tamil Nadu, India. 